\title{
STATUS GIZI BALITA
}

Widya Awalia

Universitas Islam Negeri Alauddin Makassar

Email : widyaawalia534@gmail.com

\section{Status Gizi Balita}

Status gizi balita merupakan salah satu indicator yang dapat digunakan untuk menunjukkan kualitas hidup suatu masyaralat dan juga memberikan intervensi sehingga akibat lebih buruk dapat dicegah dan perencanaan lebih baik dapat dilakukan untuk mencegah anak-anak lain dari penderitaan yang sama ( Soekiman 2000 ). Terdapat beberapa faktor yang dapat mempengaruhi status gizi anak. Faktor tersebut terbagi menjadi 2 faktor yaitu faktor internal dan eksternal. Faktor internal meliputi tingkat konsumsi individu dan penyakit infeksi yang mungkin di derita. Sedangkan faktor eksternal berupa faktor ketahanan pangan dalam keluarga, pola asuh anak, akses atau keterjangkauan anak dan keluarga terhadap air bersih dan pelayanan kesehatan yang baik (Yuliwianti, 2017).

\section{Tipe Pola Asuh Anak Disabilitas dengan Status Gizi}

Pola asuh orang tua dipengaruhi oleh beberapa faktor diantaranya adalah pengalaman masa lalu yang berhubungan erat dengan pola asuh ataupun sikap orang tua mereka, tipe kepribadian orang tua, nilai-nilai yang dianut, kehidupan perkawinan orang tua dan alasan orang tua mempunyai anak. Selain itu, Pola asuh orang tua juga dipengaruhi oleh umur, latar belakang pendidikan, pekerjaan, pengetahuan, dan jumlah anak (Warso, 2017). Secara umum, pola pengasuhan dapat mempengaruhi status gizi anak khususnya pola asuh makan. Menurut Karyadi (1985), pola asuh makan didefinisikan sebagai praktek pengasuhan yang diterapkan ibu kepada anak yang berkaitan dengan cara dan situasi makan (Isnaina, 2019). Jumlah dan kualitas makanan yang dibutuhkan untuk konsumsi anak perlu dipikirkan dan direncanakan karena dapat memberikan pengaruh yang besar terhadap keadaan status gizi anak (Indriyani, 2015). Namun pada penelitian ini, kuesioner yang digunakan kurang menggambarkan apakah orang tua juga mengontrol jumlah asupan makanan anak maupun jenis makanan yang dikonsumsi. Berdasarkan hasil penelitian diperoleh bahwa siswa dengan pola asuh permitif cenderung memiliki status gizi lebih. Pola asuh permitif merupakan pola asuh orang tua yang cenderung memberikan kesempatan pada anaknya untuk melakukan sesuatu tanpa pengawasan yang cukup termasuk dalam hal kegiatan makan. Jadwal makanan dikendalikan secara langsung oleh anak maupun dalam pemilihan makanan. Sehingga pola asuh permitif memiliki resiko 2 kali lebih besar mengalami obesitas dikarenakan anak lebih cenderung menyukai makanan-makanan yang tidak sehat dibandingkan makanan yang bergizi (Yumni, 2016). 
Pengetahuan ibu mengenai pola asuh pada anak berkebutuhan khusus sangat penting karena dengan pengetahuan yang baik akan menimbulkan kesadaran dan akhirnya dapat berperilaku sesuai dengan pengetahuan yang dimilikinya dalam hal mengasuh anak berkebutuhan khusus. Menurut Sunaryo (2004) dalam Puspitasari dan Hikmah (2019) Pengetahuan merupakan domain yang sangat penting dalam terbentuknya suatu tindakan. Pola asuh orang tua khususnya pada anak disabilitas terbagi menjadi dua yaitu pola asuh pengabaian dan pola asuh otoriter.

Pola asuh pengabaian merupakan pola asuh yang memiliki aspek demandingness dan responsiveness rendah. Demandingness rendah menunjukkan kurangnya peran ibu dalam menuntut anak untuk makan. Sedangkan responsiveness rendah menunjukkan ibu kurang tanggap dalam memenuhi kebutuhan anak terkait makan. Sehingga, makanan yang dikonsumsi oleh anak dikendalikan sendiri oleh anak tanpa adanya kontrol atau kurangnya kontrol dari orang tua (Yumni, 2016). Pola asuh pengabaian tidak menggambarkan perilaku yang sesuai dengan ajaran islam dikarenakan kurangnya peran orang tua dalam mendidik dan mengasuh anak. Pola asuh islami ditunjukkan berdasarkan sikap dan perilaku orang tua terhadap anak sejak dini berupa mendidik, membina, membiasakan dan membimbing anak secara maksimal berlandaskan AlQur'an dan Sunah. Pola asuh islami lebih menekankan pada praktik pengasuhan, dan tidak berfokus hanya pada gaya pengasuhan dalam keluarga, akan tetapi lebih fokus pada bagaimana orang tua membentuk ihsan al-kamil pada anak-anaknya. Didalam Al-Qur'an telah dijelaskan pola asuh islami yang dicontohkan oleh Luqman. Luqman memberikan pembelajaran ataupun nasihat kepada anaknya, sehingga anaknya selalu menjalankan perintah Allah SWT dan menjauhi segala larangan-Nya. Pola asuh yang diterapkan oleh Luqman diantaranya menerima kondisi anak dengan sepenuh hati, melindungi, dan menuntut kepada anak untuk selalu mengerjakan apa yang diperintahkan oleh Allah SWT.

\section{Perilaku Makan dengan Status Gizi pada Anak}

Perilaku makan pada anak berperan penting terhadap status gizi termasuk kejadian status gizi kurang dan status gizi lebih, seperti pada hasil penelitian yang telah dilakukan menunjukkan kecenderungan siswa yang memiliki status gizi lebih memiliki perilaku makan yaitu penyuka makanan. Perilaku penyuka makanan yang tinggi dapat memberikan dampak yang kurang baik terhadap kondisi kesehatan khususnya dari segi status gizi yang menyebabkan anak mengalami gizi lebih. Perilaku penyuka makanan merupakan kondisi seseorang dalam menyukai makanan berdasarkan ketertarikan terhadap makanan, keinginan untuk makan, perasaan saat makan, keinginan untuk minum, dan pemilihan jenis makanan baru yang cenderung tinggi.

status gizi lebih namun memiliki perilaku makan berupa penghindar makanan biasanya disebabkan oleh beberapa alasan, diantaranya sebagian orang tua cenderung membatasi makan anak karena adanya ketakutan terhadap anak yang mengalami obesitas khususnya bagi orang tua yang memiliki anak gangguan mental atau tunagrahita. Anak dengan gangguan mental lebih beresiko mengalami penambahan berat badan dibandingkan anak normal. Hal ini dikarenakan kesehatan mental yang buruk dapat mempengaruhi gaya hidup yang kurang sehat seperti kurang aktivitas dan lebih menyukai jenis makanan yang tidak sehat. anak dengan tunagrahita cenderung mengalami overweight atau gizi lebih dibandingkan dengan anak tunarungu yang cenderung

mengalami underweight atau gizi kurang. Keadaan tersebut disebabkan karena tingkat aktivitas 
tunagrahita yang cenderung kurang akibat keterbatasan mental yang dimiiki, sehingga perlu adanya bantuan orang lain dalam melakukan aktvitasnya dibandingkan dengan anak tunarungu yang hanya mengalami gangguan pendengaran. Karena adanya batasan dalam makanan tersebut, maka anak tunagrahita cenderung memiliki perilaku makan penghindar makanan. Sedangkan pada anak dengan disabilitas autis lebih cenderung memiliki perilaku makan yang kurang baik dan cendenrung mengalami gizi kurang. Hal ini disebabkan karena anak autis menyukai makanan yang terbatas akan gizi dan tidak menyukai beberapa jenis sayuran akibat keterbatasan dalam mencerna, menyerap, dan memfungsikan nutrisi yang masuk ke dalam tubuhnya dengan baik. Penyebab lainnya, penderita autis tidak dapat mengonsumsi makanan yang mengandung gluten dan kasein sehingga asupan gizi anak autis tidak dapat tercukupi dengan baik.

Status gizi kurang, namun memiliki perilaku makan berupa penyuka makanan. Hal ini disebabkan karena makanan yang dikonsumsi oleh anak belum mampu memenuhi kebutuhan akan gizinya, walaupun anak dikategorikan memiliki perilaku penyuka makanan. Anak dengan status gizi kurang dan memiliki perilaku penyuka makanan juga dipengaruhi oleh beberapa faktor lain salah satunya dari segi pendapatan keluarga. Rata-rata anak dengan status gizi kurang memiliki pendapatan keluarga yang rendah. Karena rendahnya pendapatan tersebut, maka keluarga cenderung kurang mampu untuk menyediakan makanan yang bergizi untuk anak. Pendapatan seseorang berpengaruh terhadap kemampuan dalam memenuhi kebutuhan makan sesuai dengan jumlah yang dibutuhkan oleh tubuh. Hal ini disebabkan karena pendapatan merupakan dasar terpenuhinya kebutuhan gizi anggota keluarga. Keluarga yang memiliki pendapatan tinggi, tentunya pemenuhan kebutuhan gizi akan lebih baik jika dibandingkan dengan keluarga yang memiliki pendapatan rendah.

\section{Social Budaya, Kepercayaan Makanan, Dukungan Keluarga dan Status gizi Kronis Balita ( Stunting )}

Kejadian balita stunting merupakan salah satu masalah gizi yang dialami oleh balita di dunia saat ini. Pada tahun 2017, 22,2\% atau sekitar 150,8 juta balita di dunia mengalami stunting. Namun angka ini sudah mengalami penurunan jika dibandingkan dengan angka stunting pada tahun 2000 yaitu 32,6\%. Pada tahun 2017, lebih dari setengah balita stunting di dunia berasal dari Asia (55\%) sedangkan lebih dari sepertiganya (39\%) tinggal di Afrika. Dari 83,6 juta balita stunting di Asia, proporsi terbanyak berasal dari Asia Selatan (58,7\%) dan proporsi paling sedikit di Asia Tengah (0,9\%). UNICEF mengemukakan sekitar $80 \%$ anak stunting terdapat di 24 negara berkembang di Asia dan Afrika, Indonesia merupakan negara urutan kelima yang memiliki prevalensi anak stunting tertinggi setelah India, China, Nigeria dan Pakistan. Sedangkan data prevalensi balita stunting yang dikumpulkan World Health Organization (WHO), Indonesia termasuk ke dalam negara ketiga dengan prevalensi tertinggi di regional Asia Tenggara/South-East Asia Regional (SEAR). Rata-rata prevalensi balita stunting di Indonesia tahun 2005-2017 adalah 36,4\% (Kementerian Kesehatan Republik Indonesia, 2018). Balita usia 24-59 bulan termasuk dalam golongan masyarakat kelompok rentan gizi (kelompok masyarakat yang paling mudah menderita kelainan gizi), sedangkan pada saat itu mereka sedang mengalami proses pertumbuhan yang relatif pesat (Ratih, 2014). Gangguan pertumbuhan linear atau stunting, terjadi terutama dalam 2 sampai 
tiga tahun pertama kehidupan dan merupakan cerminan dari efek interaksi antara kurangnya asupan energi dan asupan gizi, serta infeksi.

Pada beberapa penelitian menyatakan bahwa social budaya tidak mempengaruhi terjadinya kejadian stunting, namun beberapa penelitian juga menyatakan bahwa social budaya mempengaruhi kejadian stunting pada balita seperti budaya etnik Madura yang mengakibatkan balita mengalami stunting.

Tidak terdapat hubungan yang signifikan antara kepercayaan makanan dengan kejadian stunting. Meskipun demikian banyak ditemukan orang tua yang tidak memberikan/dipantangkan makanan tertentu kepda anaknya. Jenis makanan yang paling banyak dipantangkan kepada anak adalah daging dan sayur, dimana diketahui bahwa daging memiliki kandungan gizi protein yang tinggi sedangkan sayur memiliki kandungan zat besi yang tinggi yang berfungsi untuk mencegah terjadinya stunting. Namun beberapa jenis makan yang dipantangkan kepada anak tersebut dikarenakan alasan kesehatan seperti gatal-gatal, sehingga orang tua tidak membrikan makanan tersebut walaupun mempunyai nilai gizi yang tinggi dan dibutuhkan oleh anak dalam proses tumbuh kembangnya. Oleh karena itu orang tua harus mencari opsi atau makanan lain yang memiliki nilai gizi yang setara sehingga mampu mencegah anak mengalami stunting.

Terdapat hubungan yang signifikan antara dukungan keluarga denga kejadian stunting pada balita usia 24-59 bulan, karena dukungan keluarga sangat diperlukan seperti dukungan informasi dan instrumental sehingga keluarga mampu menyediakan waktu, biaya dan mencari informasi tentang kesehatan balita agar dapat memberikan perlakukan yang baik dan benar dalam menangani masalah kesehatan keluarga khususnya bayi dan balita.

\section{Berat Badan Lahir Rendah ( BBLR ), Kebiasaan Merokok Keluarga dan Status Gizi dengan Riwayat ISPA pada Anak}

Infeksi Saluran Pernafasan Akut (ISPA) merupakan salah satu penyebab utama kematian di dunia dan penyebab menurunnya kualitas hidup khususnya pada balita (Mokdad A.H, 2017). Hampir setiap hari sekitar 4 juta orang meninggal akibat ISPA, 98\% disebabkan oleh infeksi saluran pernafasan bawah. (Syahidi, Muh habibi., dkk, 2013). WHO mengatakan bahwa ISPA sebagai The Forgotten Killer Of Children karena sebagai pembunuh utama balita di dunia, 6,6 juta balita meninggal dunia. Maka target Rencana Aksi Program Pencegahan dan Pengendalian Penyakit 2015-2019 di Indonesia salah satunya untuk menurunkan kematian bayi dan balita dari 32 menjadi 24 per 1.000 kelahiran hidup.

Berat badan lahir rendah merupakan bayi yang lahir <2500 gram. Berat badan lahir rendah dapat menimbulkan terganggunya pertumbuhan, maturasi alat-alat, dan organ tubuh yang belum sempurna, imunitas terhadap penyakit infeksi sangat lemah, akibat dari berat badan lahir rendah dapat mengalami terjadinya infeksi dan komplikasi yang fatal pada bayi dan bahkan bisa menyebabkan mortalitas. Maka dari itu jika bayi memiliki riwayat berat badan lahir maka bayi rentan terkena ISPA sedangkan bayi yang memiliki berat badan normal tidak rentan terkena ISPA.

Kebiasaan merokok anggota keluarga yang tanpa memperhatikan lingkungan disekitar dapat menimbulkan masalah bagi perokok aktif itu sendiri dan juga menimbulkan masalah kesehatan 
bagi orang lain termasuk bayi dan balita yang tinggal bersama. Teori yang dikemukakan oleh Anthony dkk (2017) asap rokok bisa meningkatkan risiko terinfeksi ISPA. Asap rokok baik dari peghuni rumah maupun orang tua yang satu atap dapat mencemari udara, dan jika terhirup oleh anak dapat merussak pertahann saluran pernapasan, sehingga patogen penyebab ISPA rentan masuk dan dapat menginfeksi anak yang menimbulkan gejala klinis ISPA. Artinya jika bayi yang keluarganya mempunyai kebiasaan merokok maka bayi rentan terkena ISPA. Sedangkanbayi yang keluarganya tidak mempunyai kebiasaan merokok maka tidak rentan terkena ISPA.

Bayi balita dengan gizi kurang lebih rentan terhadap infeksi dan yang memiliki gizi normal seharusnya mempunyai daya tahan tubuh yang lebih baik dibandingkan bayi balita yang memiliki gizi tidak normal, karena bayi dan balita dengan gizi normal mendapatkan asupan zat gizi yang bagus untuk pertumbuhan fisik, daya tahan tubuh serta perkembangan otak.

\section{Pola Makan dan Asi Eksklusif dengan Kejadian Status Gizi Kronis ( Stunting )}

Pola Makan/Asupan Energi/Konsumsi makanan dapat memengaruhi langsung keadaan gizi atau status gizi seseorang. Asupan Energi merupakan zat yang sangat penting dalam mencegah terjadinya gizi kurang ( Stunting ). anak yang kekurangan Asupan energi memiliki risiko 1,495 kali dengan kejadian stunting. Hal ini sejalan dengan beberapa penelitian yang menyatakan bahwa terdapat hubungan positif antara asupan energi yang kurang dengan kejadian stunting. Tidak hanya itu, terdapat beberapa penelitian juga yang sejalan bahwa faktor risiko yang mempengaruhi kejadian Stunting adalah rendahnya tingkat asupan energi dengan besar risiko 7,7 kali.

ASI eksklusif tidak berperan dalam kejadian stunting pada balita karena faktor langsung dari masalah gizi adalah asupan nutrisi yang dikonsumsi oleh anak, sehingga apabila balita mendapatkan asupan nutrisi yang cukup sesuai dengan kebutuhan walaupun bayi tidak mendapatkan ASI eksklusif maka anak dapat tumbuh dengan baik. 


\section{DAFTAR PUSTAKA}

Syarfaini, Sukfitrianty Syahrir, Yusma Indah Jayadi, Andi Ainun Musfirah; Hubungan Tipe Pola Asuh Dan Perilaku Makan Dengan Status Gizi Anak Disabilitas Di SLB Negeri 1 Makassar Tahun 2020.

Maesarah, Deysi Adam, Herman Hatta, Lisa Djafar,Indriyani Ka'aba ; Hubungan Pola Makan Dan Riwayat Asi Eksklusif Dengan Kejadian Stunting Pada Balita Di Kabupaten Gorontalo.

Sukfitriyanti Syahrir, Irviani Ibrahim, Syarfaini, Yessy Kurniati, Halimatussa'diyyah ; Hubungan BBLR, Kebiasaan Merokok Keluarga, Dan Status Gizi Dengan Riwayat ISPA Bayi Di Kellurahan Ballaparang.

Irviani Ibrahim, Syamsul Alam, Andi Syamsiah Adha, Yusma Indah Jayadi, Muhammad Fadlan ; Hubungan Social Budaya Dengan Kejadian Stunting Pada Balita Usia 24-59 Bulan Di Desa BoneBone Kecamatan Baraka Kabupaten Enrekang Tahun 2020.

Sumardi Sudarman, Aswadi, Muharti Syamsul, Margareta Gabut; Hubungan Tipe Pola Asuh Dan Perilaku Makan Dengan Status Gizi, Anak Disabilitas Di SLB Negeri 1 Makassar Tahun 2020. 